\title{
Policies to Ensure Equitable Access to Well-Resourced Colleges and Universities
}

Cindy Le

Elizabeth Davidson Pisacreta

J ames Dean Ward

J esse Margolis (MarGrady Research)

Heidi Booth 


\section{ITHAKA S+R}

Ithaka S+R provides research and strategic guidance to help the academic and cultural communities serve the public good and navigate economic, demographic, and technological change. Ithaka $\mathrm{S}+\mathrm{R}$ is part of ITHAKA, a not-for-profit organization that works to advance and preserve knowledge and to improve teaching and learning through the use of digital technologies. Artstor, JSTOR, and Portico are also part of ITHAKA.

Copyright 2020 ITHAKA. This work is licensed under a Creative Commons Attribution 4.0 International License. To view a copy of the license, please see https:// creativecommons.org/licenses/by/4.0/.

ITHAKA is interested in disseminating this brief as widely as possible. Please contact us with any questions about using the report: research@ithaka.org. 
Inequity in higher education access is a persistent problem. One way in which this manifests is through inequitable opportunities to attend the most well-resourced institutions. When students attend limited-resource institutions, they are less likely to persist and earn a credential and typically have weaker labor market prospects. Low-income and racial and ethnic minority students are more likely to attend under-resourced institutions than their wealthier and white peers. These enrollment patterns vis-à-vis institutional resources stand to perpetuate social and economic inequities. In this policy brief, we describe the scope of the problem and the impacts of inequitable access. We then discuss a range of potential solutions and their implications for state policy. While increasing funding and equalizing resources across colleges would be one way to improve access to well-resourced campuses, we recognize this may not be financially or politically feasible, especially given the current economic environment. We also explore the ways that affirmative action, a streamlined application process, financial aid programs, and regulation can improve access for historically underserved students and work to narrow opportunity gaps. By addressing this issue from an array of perspectives, we believe state policymakers can develop a comprehensive strategy to improve equity in higher education.

We gratefully acknowledge the J oyce Foundation for supporting this white paper.

\section{Inequitable Access, Resources, and Outcomes}

Inequity in college access is a major problem facing American society and the economy. Lowincome, Black, and Hispanic students are all underrepresented in higher education, with the problem being particularly striking at four-year institutions. ${ }^{1}$ Black and Hispanic students in particular are underrepresented at the majority of public colleges. ${ }^{2}$ However, these racial and ethnic disparities are even larger at more selective and high-graduation-rate institutions. ${ }^{3}$ The disproportionately low enrollment rates of Black, Hispanic, and low-income students at these institutions reinforce existing social and economic stratification by limiting labor market opportunities, social mobility, and wealth creation.

These inequities have tremendous consequences for individual and societal outcomes. In fact, those who are least likely to obtain a postsecondary credential-low-income students, racial and

\footnotetext{
${ }^{1}$ Anthony P. Carnevale, Martin Van Der Werf, Michael C. Quinn, Jeff Strohl, and Dmitri Repnikov, "Our Separate \& Unequal Public Colleges: How Public Colleges Reinforce White Racial Privilege and Marginalize Black and Hispanic Students," Georgetown University Center on Education and the Workforce (2018), https://cew.georgetown.edu/cewreports/sustates/.

2 Oliver Schak, Charlie Bentley, Andrew Nichols, and Wil Del Pilar, "Broken Mirrors: Hispanic Student Representation at Public State Colleges and Universities," The Education Trust (2019), https://edtrust.org/resource/broken-mirrorsHispanic-representation-english/; Oliver Schak and Andrew Nichols, "Broken Mirrors: Black Student Representation at Public State Colleges and Universities," The Education Trust (2019), https://edtrust.org/resource/broken-mirrorsblack-representation/.

3 Elizabeth Pisacreta, Emily Schwartz, and Martin Kurzweil, "2018 ATI Impact Report," American Talent Initiative (2018), https://americantalentinitiative.org/wp-content/uploads/2018/12/American-Talent-Initiative-2018-ImpactReport.pdf.
} 
ethnic minority students, or other historically underserved groups of students-stand to benefit the most from attaining the credential. ${ }^{4}$ The lifetime earnings premium of a college degree can help close wealth gaps that exist more broadly in society. Moreover, the social returns to higher education often outpace the public investment. College graduates use fewer social services and contribute more tax revenue than non-graduates (on average, the public returns to a four-year degree are more than seven-fold), and society also benefits from the improved health outcomes, civic engagement, and family stability associated with increased postsecondary attainment. ${ }^{5}$

The benefits of earning a four-year degree at a well-resourced, selective institution are greater than those of the average four-year degree. Students at these institutions are more likely to persist and graduate, ${ }^{6}$ earn higher wages, ${ }^{7}$ and hold leadership positions. ${ }^{8}$ There is also evidence that selective college attendance improves long-term life outcomes. ${ }^{9}$ And just as historically underserved students stand to benefit the most from a postsecondary credential, the benefits of attending a selective institution are also greater for low-income and racial and ethnic minority students. ${ }^{10}$

There are proven policies and approaches that states can deploy to address inequities in college access and success, including equalizing resources across public institutions. This policy brief outlines the extent of inequities in enrollment and resources across states, explores the circumstances that contribute to these disparities, and provides a set of policy recommendations to increase access to well-resourced colleges and universities.

\footnotetext{
${ }^{4}$ Jennie E. Brand and Yu Xie, "Who Benefits Most from College? Evidence for Negative Selection in Heterogeneous Economic Returns to Higher Education," American Sociological Review 75, no. 2 (2010): 273-302, https://doi.org/10.1177\%2F0003122410363567.

5 Philip A. Trostel, "The Fiscal Impacts of College Attainment," Research in Higher Education 51, no. 3 (2010): 220247, https://doi.org/10.1007/s11162-009-9156-5; Michael Hout, "Social and Economic Returns to College Education in the United States," Annual Review of Sociology 38, (2012): 379-400, https://doi.org/10.1146/annurev.soc.012809.102503.

${ }^{6}$ Jonathan Smith, "Ova and Out: Using Twins to Estimate the Educational Returns to Attending a Selective College," Economics of Education Review 36 (2013): 166-180, https://doi.org/10.1016/j.econedurev.2013.06.008.
}

${ }^{7}$ Mark C. Long, "College Quality and Early Adult Outcomes," Economics of Education review 27, no. 5 (2008): 588602, https://doi.org/10.1016/j.econedurev.2007.04.004; Dirk Witteveen and Paul Attewell, "The Earnings Payoff from Attending a Selective College," Social Science Research 66 (2017): 154-169, https://doi.org/10.1016/j.ssresearch.2017.01.005.

8 Thomas R. Dye, Who's Running America? The Obama Reign, Routledge, 2015, https://www.routledge.com/WhosRunning-America-The-Obama-Reign-8th-Edition/Dye/p/book/9781612055558.

9 Jason M. Fletcher and David E. Frisvold, "The Long Run Health Returns to College Quality," Review of Economics of the Household 12, no. 2 (2014): 295-325, https:// http://doi.org/10.1007/s11150-012-9150-0.

10 Tatiana Melguizo, "Quality Matters: Assessing the Impact of Attending More Selective Institutions on College Completion Rates of Minorities," Research in Higher Education 49, no. 3 (2008): 214-236, https://doi.org/10.1007/s11162-007-9076-1; Stacy Berg Dale and Alan B. Krueger, "Estimating the Payoff to Attending a More Selective College: An Application of Selection on Observables and Unobservables," The Quarterly Journal of Economics 117, no. 4 (2002): 1491-1527, https://doi.org/10.1162/003355302320935089. 


\section{Inequities in Enrollment}

To understand the scope of the issue, we examine enrollment patterns across three dimensions: income representation, race and ethnicity representation, and age. Evidence suggests that lowincome, racial and ethnic minority, and adult11 students may enroll at lower rates due to a lack of information, ${ }^{12}$ family obligations, ${ }^{13}$ or an unwillingness to leave their current communities. ${ }^{14}$ On the other side, well-resourced colleges often do not actively recruit these students, which contributes to breakdowns in the pipeline. ${ }^{15}$

Disparities in access are particularly prevalent at selective institutions. Although selectivity and resources are not synonymous, selective institutions generally have more resources in the forms of fundraising, endowments, and tuition revenue dollars. Similarly, four-year public colleges have more resources than community colleges, and private nonprofit institutions, on average, have more resources than public colleges. ${ }^{16}$ The disparities that exist in relation to students' sociodemographic characteristics help explain why access to well-resourced institutions is important in the context of social stratification and broader economic trends.

\section{Income Representation}

Eighty-eight percent of 2009 ninth graders from the top income quartile enrolled in a four-year college within one year of completing high school compared to 47 percent from the lowest income quartile. ${ }^{17}$ As shown in Figure 1, individuals from low- and middle-income families enroll in public, four-year institutions at about two-thirds the rate one would expect based on their share of the college age population. ${ }^{18}$ In some states, this underrepresentation is more

\footnotetext{
${ }^{11}$ We use "adult" to refer to students who do not enter college for the first time within one year of completing high school.

12 Angela D. Bell, Heather T. Rowan-Kenyon, and Laura W. Perna, "College Knowledge of 9th And 11th Grade Students: Variation by School and State Context," The Journal of Higher Education 80, no. 6 (2009): 663-685, https://doi.org/10.1080/00221546.2009.11779039.
}

${ }^{13}$ Ryan D. Hahn and Derek Price, "Promise Lost: College-Qualified Students Who Don't Enroll in College," Institute for Higher Education Policy (2008), https://files.eric.ed.gov/fulltext/ED503317.pdf.

14 Ibid.

${ }^{15}$ Caroline M. Hoxby and Sarah Turner, "What High-Achieving Low-Income Students Know About College," American Economic Review 105, no. 5 (2015): 514-17, https://doi.org/10.1257/aer.p20151027.

${ }^{16}$ Donna M. Desrochers and Steven Hurlburt, Trends in College Spending: 2003-2013. Where Does the Money Come From? Where Does It Go? What Does It Buy? Washington: Delta Cost Project at American Institutes for Research, 2016, https://www.air.org/system/files/downloads/report/Delta-Cost-Trends-in-College\%20SpendingJanuary-2016.pdf.

17 Paul Fain, "Wealth's Influence on Enrollment and Completion," Inside Higher Ed, May 23, 2019, https://www.insidehighered.com/news/2019/05/23/feds-release-broader-data-socioeconomic-status-and-collegeenrollment-and-completion.

18 In the figure, we compare to the population age 12-17 to make it more likely that the income reflected in the ACS is their parents' income. 
extreme. In Wyoming, Delaware, Vermont, and North Dakota, students from low- and middleincome families enroll in their state's public, four-year institutions at a rate that is less than 25 percent what one would expect based on their share of the population. At the other end of the spectrum, states like New J ersey, New York, Alaska, Massachusetts, and California demonstrate more equitable access, with low- and middle-income students enrolling at rates nearly equal to or greater than their share of the state's college-age population.

Figure 1 - In the nation's public, four-year institutions, students from low- and middleincome families make up about two thirds of the enrollment one would expect based on their share of the population

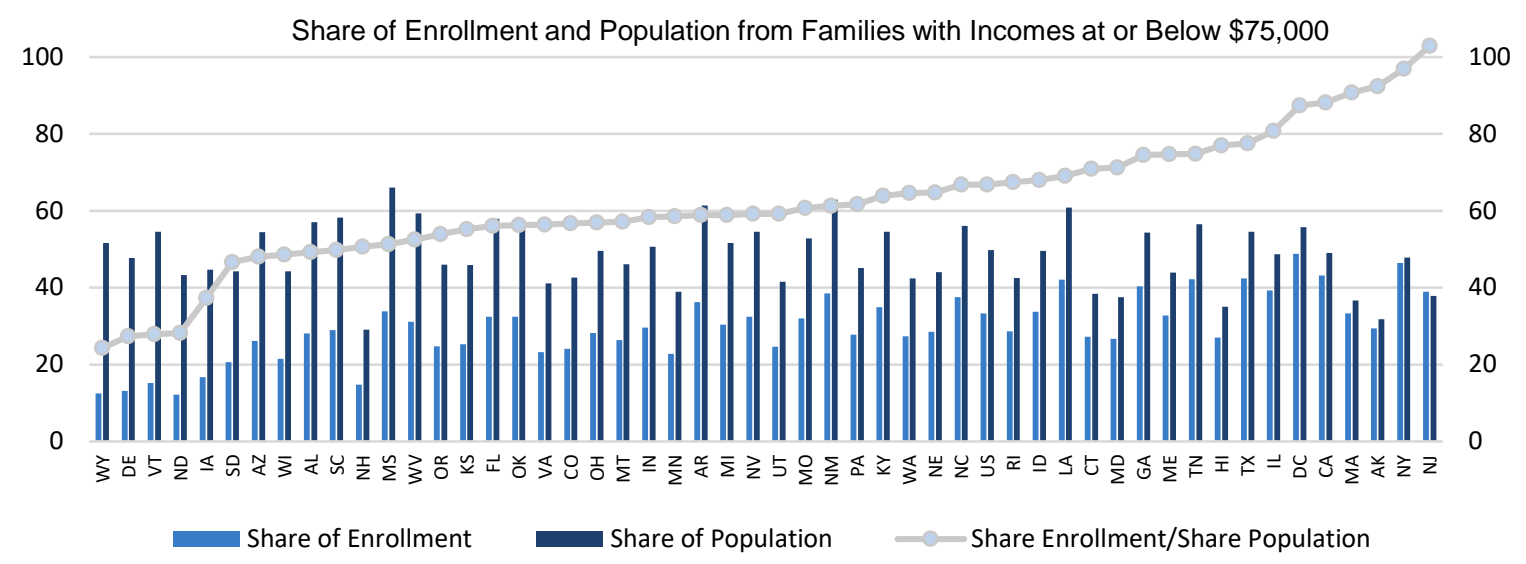

Source: IPEDS; U.S. Census Bureau's American Community Survey

The economic representativeness of four-year public college students varies across states, and it has also changed over time. As shown in Figure 2, the economic representativeness, or the representation of low- and middle-income students, of public four-year institutions in many states has improved over the past eight years. In 2009, the national share of low- and middleincome students in public four-year institutions was 53.5 percent as large as the share of lowand middle-income residents in the college-age population. By 2017, this percentage had grown to 66.8 percent, an increase of 13.3 percentage points, as shown in Figure 2. However, many states saw larger increases, with Hawaii, Alaska, and Nevada all registering gains of more than 20 percentage points on this metric. 


\section{Figure 2 - Since 2009, many states have increased the economic representativeness of their public four-year institutions}

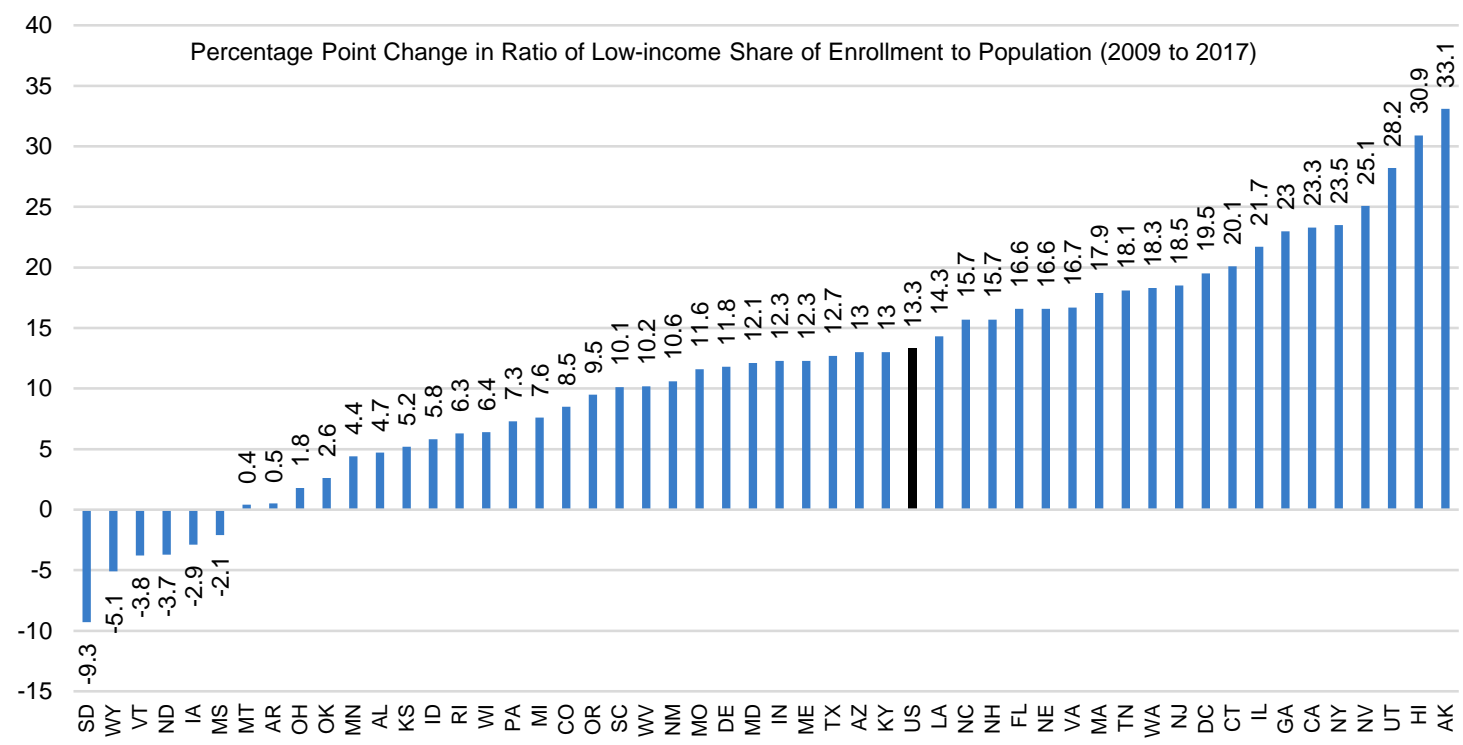

Source: IPEDS; U.S. Census Bureau's American Community Survey. Note: Neither IPEDS nor ACS income thresholds are inflation adjusted.

Improved access to public four-year institutions for low-income students is encouraging. However, there are still large enrollment disparities in many states. This lack of access for lowincome students translates into long-term differences in life and labor market outcomes. Inequitable access in the public sector leaves low-income students with fewer post-high-school options and may encourage more students to enroll in private colleges. The disproportionate share of low-income students enrolled in for-profit institutions, in particular, should be of concern given that these institutions, on average, charge higher tuition rates and have lower labor market returns than their nonprofit counterparts. ${ }^{19}$ Evidence suggests that while low- and middle-income students are underrepresented at selective institutions, bringing their access rates to parity with high-income students would substantially close intergenerational wage gaps. ${ }^{20}$ Given that the economic mobility benefits of higher education increase as a student's family income decreases, redistributing seats in the most well-resourced institutions to lowincome students is likely to decrease wealth inequities.

${ }^{19}$ David Deming, Claudia Goldin, and Lawrence Katz, "For-Profit Colleges," The Future of Children (2013): 137-163, https://www.jstor.org/stable/23409492.

${ }^{20}$ Raj Chetty, John N. Friedman, Emmanuel Saez, Nicholas Turner, and Danny Yagan, "Income Segregation and Intergenerational Mobility across Colleges in the United States," The Quarterly Journal of Economics 135, no. 3 (2020): 1567-1633, https://doi.org/10.1093/qje/qjaa005. 


\section{Racial and Ethnic Representation}

Enrollment disparities also exist across racial and ethnic lines. Though discrepancies in collegegoing rates have narrowed in some respects, stark racial inequities remain. For instance, while the gap in college-going rates between white and Hispanic students narrowed from 18 to eight percentage points between 2003 and 2013, the gap between white and Black students' collegegoing rates remained roughly the same. ${ }^{21}$ Enrollment data from recent years shows that roughly 70 percent of high school graduates enroll directly in college, and white and Hispanic students enroll at rates similar to this national average. However, nearly 90 percent of Asian students enroll directly in a postsecondary institution compared to 57 percent of Black students. ${ }^{22}$

These enrollment disparities are particularly apparent at selective institutions, where student populations are rarely representative of the racial and ethnic diversity of states. For example, Florida is the only state where the number of Hispanic students at selective public universities is proportional to the Hispanic college-age population in the state. Additionally, no state has a representative share of Black students in selective public colleges. ${ }^{23}$ The problem is particularly pronounced at the most selective public and private institutions, where in many cases Black and Hispanic students are more underrepresented than in the past. ${ }^{24}$

White and Asian students are more likely to enroll at more selective institutions, four-year colleges, and private nonprofit institutions than their Black and Hispanic peers. Similar to lowincome students, Black and Hispanic students are overrepresented at for-profit institutionswhere graduates face higher rates of unemployment, higher levels of debt, and are more likely to default on student loans. ${ }^{25}$

\section{Adult Learners}

In addition to better understanding the underrepresentation of Black, Hispanic, and low-income students at selective institutions, states should also examine inequities in access to higher

\footnotetext{
${ }^{21}$ Lauren Musu-Gilette, Jennifer Robinson, Joel McFarland, Angelina KewalRamani, Anlan Zhang, and Sidney Wilkinson-Flicker, "Status and Trends in the Education of Racial and Ethnic Groups 2016," Washington, DC: National Center for Education Statistics (2016), https://nces.ed.gov/pubs2016/2016007.pdf.

${ }^{22}$ Lorelle L. Espinosa, Jonathan M. Turk, Morgan Taylor, and Hollie M. Chessman, "Race and Ethnicity in Higher Education: A Status Report," Washington, DC: American Council on Education (2019), https://www.equityinhighered.org/resources/report-downloads/.

${ }^{23}$ Anthony P. Carnevale, Martin Van Der Werf, Michael C. Quinn, Jeff Strohl, and Dmitri Repnikov, "Our Separate \& Unequal Public Colleges: How Public Colleges Reinforce White Racial Privilege and Marginalize Black and Hispanic Students," Georgetown University Center on Education and the Workforce (2018), https://cew.georgetown.edu/cewreports/sustates/.

${ }^{24}$ Jeremy Ashkenas, Haeyoun Park, and Adam Pearce, "Even With Affirmative Action, Blacks and Hispanics Are More Underrepresented at Top Colleges Than 35 Years Ago," New York Times (2017), https://www.nytimes.com/interactive/2017/08/24/us/affirmative-action.html; Andrew Howard Nichols, "Segregation Forever?," The Education Trust, (2020), https://edtrust.org/resource/segregation-forever/.

25 David Deming, Claudia Goldin, and Lawrence Katz, "For-Profit Colleges," The Future of Children (2013): 137-163, https://www.jstor.org/stable/23409492.
} 
education for adult learners. Today, nearly 40 percent of students enrolling in higher education are over the age of $25 .{ }^{26}$ Not only will states be unable to meet their postsecondary attainment goals without increasing the attainment of adult learners, ${ }^{27}$ the current economic downturn is likely to drive many more adults back to higher education for retraining and upskilling. ${ }^{28}$ However, adult learners often face a unique set of obstacles that influence both their ability to enroll in college and the resources available to them once enrolled.

While improving the attainment of adult learners will require states to enroll older students at higher rates, there are frequently institutional barriers associated with enrolling adult learners in higher education. First, older students often face financial and logistical challenges when enrolling in college. For instance, adult learners are more likely to end up attending multiple postsecondary institutions, ${ }^{29}$ but many students lose credits when transferring to a new institution. ${ }^{30}$ This can increase both the time and cost associated with completing a degree. Older students are also more likely to be raising children while attending college, ${ }^{31}$ and the declining availability of child care for college students may make it increasingly difficult for students with children to balance school and family responsibilities. ${ }^{32}$ Without adequate support, these and similar challenges may discourage adult learners from enrolling in higher education.

For those who do enroll, adult learners are also less likely to attend "traditional" residential campuses, which are often the most well-resourced. ${ }^{33}$ Alternatively, older students are more

\footnotetext{
${ }^{26}$ National Center for Education Statistics, "Fast Facts: Back to School Statistics," https://nces.ed.gov/fastfacts/display.asp?id=372.
}

27 James Dean Ward, Jesse Margolis, Benjamin Weintraut, and Elizabeth Davidson Pisacreta, "Raising the Bar: What States Need to Do to Hit Their Ambitious Higher Education Attainment Goals," Ithaka S+R, 13 February 2020, https://doi.org/10.18665/sr.312647.

${ }^{28}$ Andrew Barr and Sarah Turner, "Out of Work and into School: Labor Market Policies and College Enrollment during the Great Recession," Journal of Public Economics 124 (2015): 63-73, https://doi.org/10.1016/j.jpubeco.2014.12.009.

${ }^{29}$ Karyn E. Rabourn, Allison BrckaLorenz, and Rick Shoup, "Reimagining Student Engagement: How Nontraditional Adult Learners Engage in Traditional Postsecondary Environments," The Journal of Continuing Higher Education 66, no. 1 (2018): 22-33, https://www.tandfonline.com/doi/abs/10.1080/07377363.2018.1415635.

30 United States Government Accountability Office (GAO), "Higher Education: Students Need More Information to Help Reduce Challenges in Transferring College Credits." (2017), https://www.gao.gov/products/GAO-17-574.

${ }^{31}$ Sara Goldrick-Rab, Carrie R. Welton, and Vanessa Coca, "Parenting While in College: Basic Needs Insecurity Among Students with Children," (2020), https://hope4college.com/wpcontent/uploads/2020/05/2019 ParentingStudentsReport.pdf.

32 Barbara Gault, "Child Care for Parents in College: A State-By-State Assessment," Institute for Women's Policy Research, (2016).

${ }^{33}$ Wendy Samuels, Andrea L. Beach, and Louann Bierlein Palmer, "Persistence of Adult Undergraduates on a Traditionally-Oriented University Campus: Does Donaldson and Graham's Model of College Outcomes for Adult Students Still Apply?" Journal of College Student Retention: Research, Theory \& Practice 13, no. 3 (2011): 351-371, https://doi.org/10.2190\%2FCS.13.3.e; Joseph C. Chen, "Nontraditional Adult Learners: The Neglected Diversity in Postsecondary Education," SAGE Open 7, no. 1 (2017), https://doi.org/10.1177\%2F2158244017697161. 
likely to take courses online and enroll in college part-time. ${ }^{34}$ Whereas the majority of students under 25 are full-time students, nearly 60 percent of adult learners attend college part time. ${ }^{35}$ Colleges that serve more part-time students-such as community colleges-often have access to fewer resources. Similarly, prior to COVID-19, online course-taking has traditionally been much less common at selective institutions and much more common at for-profit institutions. ${ }^{36}$ These enrollment and attendance patterns of adult learners suggest that adult learners are more likely to enroll in less selective and limited-resource institutions, which are negatively associated with both attainment rates and long-term life outcomes. As one of the fastest growing student populations, access to high-quality postsecondary opportunities for adult learners will be critical to sustain a skilled workforce.

\section{Drivers of Inequity}

To understand how enrollment patterns translate into disparate opportunities, we examine two forms of inequity. First, we examine the pipeline to postsecondary education and how geographic and economic factors, as well as student-level characteristics, impact application and enrollment decisions. We show how these factors culminate in "undermatching" and the implications of this on student outcomes. Second, we discuss the inequitable distribution of resources across institutions. This combination of inequitable enrollment patterns and funding disparities result in limited opportunities for historically underserved students.

\section{Inequities in the pipeline}

Geographic and economic factors play an important role in students' opportunities. Idiosyncrasies in geography, ${ }^{37}$ urbanicity, ${ }^{38}$ and regional economies ${ }^{39}$ may influence the likelihood an individual attends college. For example, some students may be unwilling or unable to relocate for college due to family relationships or obligations. In fact, most college students

\footnotetext{
${ }^{34}$ Karyn E. Rabourn, Allison BrckaLorenz, and Rick Shoup, "Reimagining Student Engagement: How Nontraditional Adult Learners Engage in Traditional Postsecondary Environments," The Journal of Continuing Higher Education 66, no. 1 (2018): 22-33, https://www.tandfonline.com/doi/abs/10.1080/07377363.2018.1415635.

35 National Center for Education Statistics, "Trend Generator," https://nces.ed.gov/ipeds/TrendGenerator/app/buildtable/2/8?rid=89\&ridv=8\%7C9\%7C10\%7C11\%7C12\&cid $=80$.

${ }^{36}$ David J. Deming, Claudia Goldin, Lawrence F. Katz, and Noam Yuchtman, "Can Online Learning Bend the Higher Education Cost Curve?," American Economic Review 105, no. 5 (2015): 496-501, https://scholar.harvard.edu/files/ddeming/files/aer.p20151024.pdf.

37 Nicholas W. Hillman, "Geography of College Opportunity: The Case of Education Deserts," American Educational Research Journal 53, no. 4 (2016): 987-1021, https://doi.org/10.3102\%2F0002831216653204.

${ }^{38}$ William G. Tierney and Linda Serra Hagedorn, Increasing Access to College: Extending Possibilities for All Students, SUNY Press, 2002, https://www.sunypress.edu/p-3578-increasing-access-to-college.aspx.

${ }^{39}$ Andrew Foote and Michel Grosz, "The Effect of Local Labor Market Downturns on Postsecondary Enrollment and Program Choice," Education Finance and Policy (2019): 1-50, https://doi.org/10.1162/edfp a 00288.
} 
attending a public four-year college enroll in an institution within 50 miles of their home. ${ }^{40}$ Additionally, low-income students who live near a selective public institution are more likely to attend a selective college, regardless of whether or not they remain local. ${ }^{41}$

Local economies may also impact college-going. The number of "good jobs"—which are defined as paying at least $\$ 35,000$ per year - that do not require a bachelor's degree decreased in the northeast from 1991 through 2015 but grew by more than 50 percent in Nevada, Utah, and the Dakotas. ${ }^{42}$ The types of jobs available, as a result of local economies, may influence the extent to which high school graduates value higher education and the type of educational and career guidance they receive from high school counselors. ${ }^{43}$ In turn, disparities in who is encouraged to apply to postsecondary institutions may reduce the likelihood of historically underserved students applying to and matriculating in college.

Similarly, geographically bound economies and politics impact important K-12 factors that affect college-going rates. Negative local economic shocks and local politics can adversely impact K-12 spending, which in turn affects students' likelihood of enrolling in college. ${ }^{44}$ These contextual factors that influence a student's educational trajectory are important for understanding inequities in postsecondary access and enrollment.

While geographic factors play a large role in shaping students' K-12 experiences and postsecondary interests, there are also many institutional barriers associated with the college application and admissions processes. In particular, inequities in standardized test preparation, college recruitment, admissions decisions, and transfer policies heavily influence students' postsecondary opportunities. These inequities not only impact students' likelihood of applying to and enrolling in college but also the range and quality of postsecondary educational options available to them.

Standardized admissions tests have historically served as a barrier to postsecondary enrollment for many students. Inequitable access to information about college entrance exams and test

\footnotetext{
40 Nicholas Hillman and Taylor Weichman, "Education Deserts: The Continued Significance of "Place" in the TwentyFirst Century," Viewpoints: Voices from the Field (2016), https://www.acenet.edu/Documents/Education-Deserts-TheContinued-Significance-of-Place-in-the-Twenty-First-Century.pdf.

${ }^{41}$ Chau Do, "The Effects of Local Colleges on the Quality of College Attended," Economics of Education Review 23, no. 3 (2004): 249-257, https://doi.org/10.1016/j.econedurev.2003.05.001.

42 Anthony P. Carnevale, Je Strohl, and Neil Ridley, "Good Jobs that Pay without a BA," Washington: Georgetown Center for Education and the Workforce, 2017, https://goodjobsdata.org/wp-content/uploads/Good-Jobs-States.pdf.

${ }^{43}$ Laura W. Perna, "Studying College Access and Choice: A Proposed Conceptual Model," In Higher Education: Handbook of Theory and Research, vol. 21, pp. 99-157. Springer, Dordrecht, 2006, https://doi.org/10.1007/1-40204512-3 3 .

${ }^{44}$ C. Kirabo Jackson, Rucker C. Johnson, and Claudia Persico, "The Effects of School Spending on Educational and Economic Outcomes: Evidence from School Finance Reforms," The Quarterly Journal of Economics 131, no. 1 (2016): 157-218, https://doi.org/10.1093/qje/qjv036.
}

C. Kirabo Jackson, Cora Wigger, and Heyu Xiong, "Do School Spending Cuts Matter? Evidence from the Great Recession," No. w24203, National Bureau of Economic Research, 2018, https://www.nber.org/papers/w24203. 
preparation across high schools and students contribute to racial and socioeconomic disparities in outcomes. ${ }^{45}$ As a primary driver of admissions at the most selective and well-resourced institutions, disparities in SAT scores contribute to the discrepancies in enrollment rates for different subgroups of students.

As evidence continues to emerge regarding exam bias and as researchers question the ability of college entrance exams to predict postsecondary success, ${ }^{46}$ some institutions and college systems have adopted test-optional policies (TOPs). Such policies do not require undergraduate applicants to submit SAT or ACT scores in order to be considered for admission. Early evidence on the effects of TOPs show mixed results, and it may be too early to see the long-term impacts of TOPs on enrollment disparities. However, TOPs tend to increase the number of applications a college receives, and research suggests that students from underrepresented racial groups, firstgeneration students, women, and Pell Grant recipients, are more likely to take advantage of testoptional policies. ${ }^{47}$

In addition to facing lower rates of college enrollment overall, low-income students are also less likely than their affluent peers to apply to selective colleges, regardless of academic preparation and ability. ${ }^{48}$ The other side of the same coin, however, is that highly selective institutions have historically failed to recruit low-income students. ${ }^{49}$ These effects may be compounded by geographic factors as well. Low-income students who live far from selective institutions are less likely to apply than their nearby counterparts, 50 and colleges often use geographic bounds in their recruitment that systematically exclude low-income and racial and ethnic minority students. 51

\footnotetext{
${ }^{45}$ Claudia Buchmann, Dennis J Condron, and Vincent J. Roscigno, "Shadow Education, American Style: Test Preparation, the SAT and College Enrollment," Social Forces, Vol. 89, No. 2, (2014), 435-361, https://www.jefftk.com/buchmann2010.pdf.

46 John L. Hoffman and Katie E. Lowitzki, "Predicting College Success with High School Grades and Test Scores: Limitations for Minority Students," The Review of Higher Education, Vol. 28, No. 4 (2005): 455-474, https://eric.ed.gov/?id=EJ744073.

${ }^{47}$ William C. Hiss and Valerie W. Franks, "Defining Promise: Optional Standardized Testing Policies in American College and University Admissions," The National Association for College Admissions Counseling (2014), https://www.luminafoundation.org/files/resources/definingpromise.pdf.
}

48 Karen Jeong Robinson and Josipa Roksa, "Counselors, Information, and High School College-Going Culture: Inequalities in the College Application Process," Research in Higher Education 57, no. 7 (2016): 845-868, https://doi.org/10.1007/s11162-016-9406-2.

${ }^{49}$ Catharine Bond Hill and Gordon C. Winston, "Low-Income Students and Highly Selective Private Colleges: Geography, Searching, and Recruiting," Economics of Education Review 29, no. 4 (2010): 495-503, https://doi.org/10.1016/j.econedurev.2009.12.004.

${ }^{50}$ Amanda L. Griffith and Donna S. Rothstein, "Can't Get there from here: The Decision to Apply to a Selective College," Economics of Education Review 28, no. 5 (2009): 620-628, https://doi.org/10.1016/j.econedurev.2009.01.004.

51 Ozan Jaquette and Karina Salazar, "Colleges Recruit at Richer, Whiter High Schools," New York Times (2018), https://www.nytimes.com/interactive/2018/04/13/opinion/college-recruitment-rich-white.html. 
Institutions' admissions processes may also restrict the enrollment of low-income students. Many private colleges and some public colleges either explicitly or implicitly consider a students' ability to pay in making admissions decisions. Private colleges are more likely to do this explicitly, but selective public colleges implicitly manage their revenues by increasing their enrollment of out-of-state or international students, who are more likely to pay full price. ${ }^{52} \mathrm{By}$ default, these admissions practices likely limit opportunities for low-income students.

Selective institutions often cite a lack of high-achieving, low-income students as the cause for disproportionately low enrollment rates of low-income students. However, research shows there is an untapped well of highly capable low-income students and that the issue of underrepresentation is not due to lack of talent or preparation. In fact, low-income high achievers who apply to selective institutions are admitted and graduate at high rates. ${ }^{53}$

Inequities in the pipeline to postsecondary education culminate in reduced opportunities for historically underserved students and a greater likelihood that students will "undermatch." Undermatching is a phenomenon in which a student enrolls in college that is less selective or has lower admissions standards than the student's credentials. Undermatching is not inherently bad-there are a multitude of factors that students consider when choosing a college, and perceived prestige and selectivity should not be the sole factor in selecting an institution. However, undermatching is important when considering access to postsecondary resources. The most selective institutions are often the most well-resourced and can provide the most opportunities to students.

Research shows that roughly four out of ten students undermatch in their college choice and that undermatching disproportionately impacts students who are low-income, underrepresented minorities, and live in rural areas. ${ }^{54}$ Researchers have demonstrated that eliminating undermatching would result in fewer high-income and more middle-income students in selective institutions. 55

\footnotetext{
52 Ozan Jaquette, Bradley R. Curs, and Julie R. Posselt, "Tuition Rich, Mission Poor: Nonresident Enrollment Growth and the Socioeconomic and Racial Composition of Public Research Universities," The Journal of Higher Education 87, no. 5 (2016): 635-673, https://doi.org/10.1080/00221546.2016.11777417.

${ }^{53}$ Caroline M. Hoxby and Christopher Avery, "The Missing" One-Offs": The Hidden Supply of High-Achieving, LowIncome Students," Cambridge: National Bureau of Economic Research, 2012, https://www.nber.org/papers/w18586.pdf.

54 Jonathan Smith, Matea Pender, and Jessica Howell, "The Full Extent of Student-College Academic Undermatch," Economics of Education Review 32 (2013): 247-261, https://doi.org/10.1016/j.econedurev.2012.11.001.

Sandra E. Black, Kalena E. Cortes, and Jane Arnold Lincove, "Academic Undermatching of High-Achieving Minority Students: Evidence from Race-Neutral and Holistic Admissions Policies," American Economic Review 105, no. 5 (2015): 604-610, https:// http://doi.org/10.1257/aer.p20151114.

${ }^{55}$ Raj Chetty, John Friedman, Emmanuel Saez, Nick Turner, and Danny Yagan, "The Determinants of Income Segregation and Intergenerational Mobility: Using Test Scores to Measure Undermatching," NBER Working Paper w26748 (2020), https://www.nber.org/papers/w26748.
} 
The inequities in the pipeline, which often manifest in undermatching, help explain why the enrollment patterns described above persist. These breakdowns in the pipeline to higher education diminish the opportunities for all students to have an equal chance at attending the most well-resourced institutions.

\section{Inequities in Resources}

Disparities across institutions are reflected in student outcomes. The median graduation rate at four-year institutions is 77 percent, compared to 38 percent at two-year colleges. ${ }^{56}$ Research also shows that attending a four-year college instead of a two-year college increases the marginal student's likelihood of earning a bachelor's degree. ${ }^{57}$ Importantly, these attainment gaps translate to disparities in long-term life outcomes including earning and loan repayment rates. ${ }^{58}$ Moreover, earning a bachelor's degree is associated with double the lifetime earnings as only having a high school diploma, and roughly 30 percent more than only having an associate's degree. This variation across colleges is largely driven by disparities in resources.

Research shows us that when colleges spend more resources on students, graduation rates increase and long-term life and labor market outcomes improve. ${ }^{59} \mathrm{~A}$ recent study found that, in particular, increased spending on instruction is associated with increases in bachelor's degree completion rates for low-income students. ${ }^{60}$ When students have the opportunity to attend wellresourced institutions, their outcomes improve. These benefits can help mitigate persistent social and economic inequities as well as improve the economic and financial outlook for states.

Spending inequities persist across racial and ethnic lines. A recent analysis shows that average state higher education spending on Black and Hispanic students is more than \$1,000 less than average public spending on white students. ${ }^{61}$ Minority-Serving Institutions (MSIs) also have lower total revenues than non-MSIs. Although both groups of institutions receive similar per

\footnotetext{
${ }^{56}$ Michael Itzkowitz, "The State of American Higher Education Outcomes in 2019," Washington, DC: Third Way (2019), https://www.thirdway.org/report/the-state-of-american-higher-education-outcomes-in-2019.

57 Joshua Goodman, Michael Hurwitz, and Jonathan Smith, "Access to 4-Year Public Colleges and Degree Completion," Journal of Labor Economics 35, no. 3 (2017): 829-867, https://doi.org/10.1086/690818

58 Ibid.

59 David J. Deming and Christopher R. Walters, "The Impact of Price Caps and Spending Cuts on US Postsecondary Attainment," Cambridge: National Bureau of Economic Research, 2017, https://doi.org/10.3386/w23736.

Rajashri Chakrabarti, Nicole Gorton, and Michael F. Lovenheim, "The Effect of State Funding for Postsecondary Education on Long-Run Student Outcomes," Cambridge: National Bureau of Economic Research, 2017, http://conference.iza.org/conference files/WoLabConf 2018/chakrabarti r26265.pdf.

60 Jeremy Wright-Kim, Laura W. Perna, and Roman Ruiz, "Institutional Characteristics and Bachelor's Degree Completion of Pell Grant Recipients," Journal of College Student Retention: Research, Theory \& Practice (2019), https://doi.org/10.1177/1521025119892934.

${ }^{61}$ Sara Garcia, "Gaps in College Spending Shortchange Students of Color," Washington, DC: Center for American Progress (2018), https://www.americanprogress.org/issues/educationpostsecondary/reports/2018/04/05/448761/gaps-college-spending-shortchange-students-color/.
} 
FTE funding from states, MSIs typically have lower tuition and provide more discounting to maintain affordability for their students who have lower incomes, on average, than non-MSI students. For this reason, four-year MSI revenues, and thus educational expenditures, are roughly half that of non-MSIs. ${ }^{62}$ These revenue patterns are often perpetuated or exacerbated by other state policies. For example, in states that have adopted performance-based funding (PBF) policies, public MSIs receive significantly less funding under the policy than public non-MSIs. Moreover, public MSIs in PBF states receive less funding than public MSIs in non-PBF states. ${ }^{63}$

Broadly, there is significant variation in resources and per-student spending across different types of institutions. At public research universities, which are often more selective and include the flagship institutions, per full-time equivalent student (FTE) spending is roughly twice that of public bachelor's and master's institutions, which generally include regional comprehensive colleges. However, per FTE spending at community colleges-which disproportionately enroll students from underrepresented racial groups ${ }^{64}$-is roughly one-third the amount of public research universities. Among private colleges, research universities spend more than twice the amount of bachelor's and master's degree institutions. ${ }^{65}$ Importantly, these gaps widened in the years following the Great Recession. Given the potential economic impact of the current Covid19 pandemic, inequity in the distribution of resources across institutions may widen.

In addition to funding disparities across different types of institutions, there is also considerable state-by-state variation. Figure 3 shows the per FTE state and local appropriations at public colleges and universities. Even when accounting for the relative wealth of states, the funding effort varies greatly. In fact, some of the wealthiest states fund their public higher education at the lowest levels. This is particularly important for low-income students attending public institutions who may be left with poorly resourced institutions as the only affordable option.

\footnotetext{
62 Alisa Cunningham, Eunkyoung Park, and Jennifer Engle, "Minority-Serving Institutions: Doing More with Less," Washington, DC: Institute for Higher Education Policy (2014), http://www.ihep.org/research/publications/minorityserving-institutions-doing-more-less.

${ }^{63}$ Nicholas Hillman and Daniel Corral, "The Equity Implications of Paying for Performance in Higher Education," American Behavioral Scientist 61, no. 14 (2017): 1757-1772, https://doi.org/10.1177\%2F0002764217744834.

64 The Institute for College Access \& Success, "Inequitable Funding, Inequitable Results: Racial Disparities at Public Colleges," Oakland: TICAS (2019), https://ticas.org/wp-content/uploads/legacy-files/pub files/inequitable funding inequitable results.pdf.

65 Donna M. Desrochers and Steven Hurlburt, "Trends in College Spending: 2003-2013. Where Does the Money Come From? Where Does It Go? What Does It Buy?" Delta Cost Project at American Institutes for Research (2016), https://www.air.org/system/files/downloads/report/Delta-Cost-Trends-in-College\%20Spending-January-2016.pdf.
} 
Figure 3 - Variation in State Public Higher Education Funding and Funding Effort

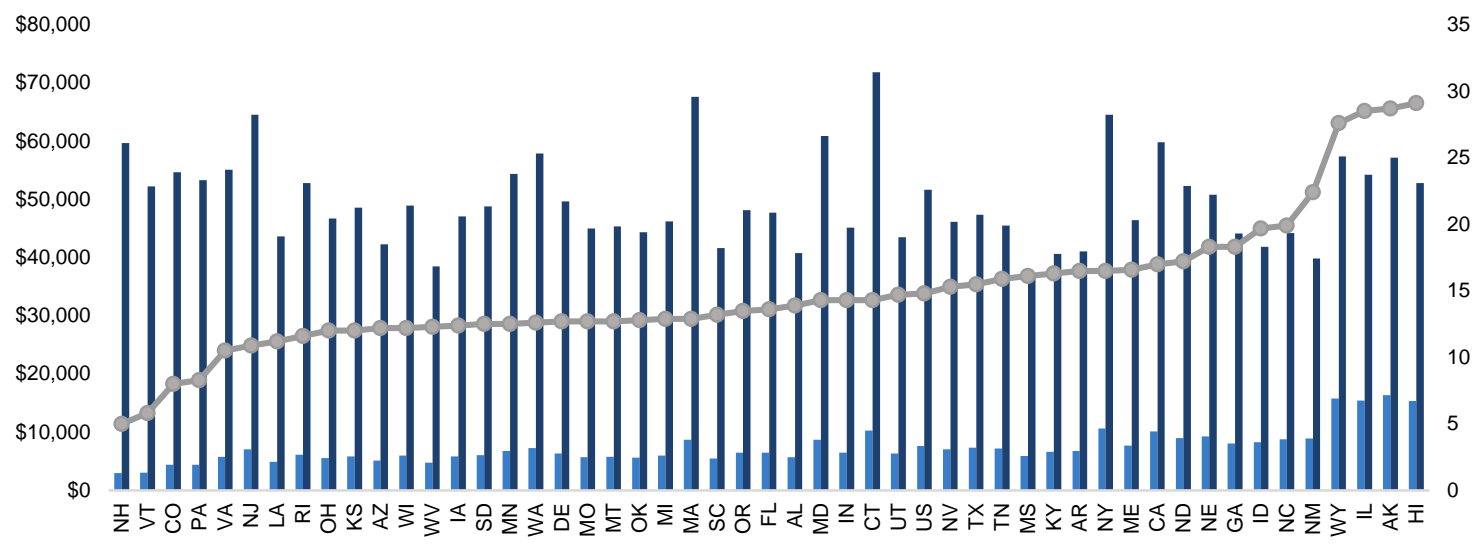

State \& Local Appropriations per FTE (2017) — Mean Personal Income (2017) — — - Appopriations per FTE / Mean Income (\%)

Source: State Higher Education Executive Officer's Association (SHEEO); U.S. Bureau of Labor Statistics. U.S. Bureau of Economic Analysis. Note: all dollar figures are inflation-adjusted using the CPI to be in 2018 dollars.

Given the need for more college-educated individuals in the labor market, closing postsecondary enrollment and attainment gaps is an economic imperative if the United States is to continue to be successful in the global economy. ${ }^{66}$ From the perspective of an individual state, improving access to well-resourced colleges increases the human capital and employability of residents. Moreover, closing opportunity gaps has the benefit of reducing low-income residents' need for additional social services. Below we discuss a range of ways states have sought to address inequitable access to well-resourced institutions. Because inequity in postsecondary resources and opportunities is multi-faceted, we focus on a diverse set of solutions. We do not suggest any single solution is a panacea to the opportunity gap, but rather, each policy is an additional tool that state leaders can use to improve access to well-resourced institutions.

\section{Policy Recommendations}

We believe state policy can play a proactive role in improving access to the most well-resourced institutions and thus reduce opportunity gaps for historically underserved student groups. Here we discuss the ways in which state leaders can address both inequities in the pipeline to postsecondary institutions and inequities in resources at these institutions. Our solutions focus on ways to improve access to well-resourced colleges, equalize resources across institutions, and ensure institutional quality.

\footnotetext{
${ }^{66}$ Anthony P. Carnevale, Nicole Smith, and Jeff Strohl, "Recovery: Job Growth and Education Requirements through 2020," Washington, DC: Georgetown Center for Education and the Workforce (2014), https://cew.georgetown.edu/wp-content/uploads/2014/11/Recovery2020.ES .Web .pdf.
} 


\section{Affirmative Action as a Solution}

Historically, the primary policy to improve access to underrepresented groups-particularly underrepresented racial and ethnic groups - has been through affirmative action. However, after California's ban was enacted in 1998, the percentage of students who were underrepresented minorities at University of California's four highest ranked campuses dropped from about 20 percent to less than 15 percent and there was a corresponding, though slightly smaller, increase in the racial and ethnic minority share at the four lowest ranked campuses. ${ }^{67}$ Given the concentration of resources at research institutions and highly-selective public colleges, shifts in enrollment demographics likely have long-term impacts on graduation rates and social mobility for students from underrepresented groups.

To promote diverse educational environments even with affirmative action bans in place, many states have turned to "percent plans," which guarantee admission to the highest-performing students from each high school in the state. The Texas Ten Percent Plan, developed in 1997, was one of the first. The plan guarantees admission to any state public university to any graduate in the top ten percent of their high school class. ${ }^{68}$ However, one study found that the average retention and graduation rates of racial and ethnic minority students fell when Texas transitioned from an affirmative action plan to the Top Ten Percent Plan. Importantly, the study estimated that 90 percent of the increase in the graduation gap between minorities and nonminorities in Texas was due to the affirmative action ban. The authors declared that "affirmative action is the most efficient policy to diversify college campuses, even in highly segregated states like Texas."69

When researchers simulated the impact of various "percent plan" enrollment policies in other states, no states and no policies maintained the level of racial and ethnic minority representation achieved under affirmative action policies. ${ }^{70}$ In fact, a study based on simulations found that if there were a nationwide ban on race-based higher education admissions, racial and ethnic minority enrollment would decrease by two percent across all U.S. colleges and

\footnotetext{
67 The top four public colleges are the four in the U.C. system that were the highest ranked in the 1995 U.S. News \& World Report rankings: UC Berkeley, UCLA, UC Davis, and UCSD. The bottom four are the other four campuses that offered undergraduate education at that time: UC Irvine, UC Riverside, UC Santa Barbara, and UC Santa Cruz. Peter Hinrichs, "The Effects of Affirmative Action Bans on College Enrollment, Educational Attainment, and the Demographic Composition of Universities," Review of Economics and Statistics 94, no. 3 (2012): 712-722, https://doi.org/10.1162/REST a 00170.

${ }^{68}$ Lindsay Daugherty, Paco Martorell, and Isaac Mcfarlin, "The Texas Ten Percent Plan's Impact on College Enrollment," Education Next 14, no. 3 (2014): 62-70, https://www.educationnext.org/texas-ten-percent-plans-impactcollege-enrollment/.

${ }^{69}$ Kalena E. Cortes, "Do Bans on Affirmative Action Hurt Minority Students? Evidence from the Texas Top 10\% Plan," Economics of Education Review 29, no. 6 (2010): 1110-1124, https://doi.org/10.1016/i.econedurev.2010.06.004.

70 Daniel Klasik, "Can a Percent Plan be a Successful Race-Neutral Alternative to Race-Conscious Affirmative Action in Maryland?" College Park: Maryland Equity Project, 2015, https://education.umd.edu/file/8603/download?token=ojFwp72S.
} 
universities. For the most selective schools, the decrease could be more than ten percent. ${ }^{11}$ The authors of the study found that race-blind selection models had negative effects on both racial and socioeconomic diversity, and boosting racial diversity is only possible if race is a factor in admissions decisions. ${ }^{72}$

Another report found that colleges could use income-based affirmative action programs and maintain similar levels of racial and ethnic representation. ${ }^{73}$ However, such a program would ignore the structural biases that impact racial and ethnic minority students from higher socioeconomic (SES) backgrounds. Finally, a recent simulation study showed that the combination of an SES-based affirmative action program and targeted racial and ethnic minority recruitment could result in similar levels of diversity as traditional affirmative action programs, but the enrolled class would likely have lower high school grades. ${ }^{74}$

Some critics of affirmative action point to a "mismatch" hypothesis, where students who are admitted under affirmative action will be academically unprepared for college. ${ }^{75}$ However, studies have shown that students_regardless of race or income - are most likely to graduate if they attend the most selective institution to which they are admitted. ${ }^{76}$ In fact, more disadvantaged students have the most to gain from attending a higher quality institution, and there is little evidence that student outcomes are negatively affected by attending a highly selective college. ${ }^{77}$ Finally, the simulation study discussed above showed that academic overmatch is not a significant concern of affirmative action policies. ${ }^{78}$

\footnotetext{
71 Jessica S. Howell, "Assessing the Impact of Eliminating Affirmative Action in Higher Education," Journal of Labor Economics 28, no. 1 (2010): 113-166, https://www.doi.org/10.1086/648415.

72 Anthony P. Carnevale, Jeff Strohl, and Stephen J. Rose, "Achieving Racial and Economic Diversity with Race-Blind Admissions Policy," Georgetown University Center on Education and the Workforce, 2014, https://vtechworks.lib.vt.edu/bitstream/handle/10919/83053/AchievingRacialEconomicDiversity.pdf.

73 Richard D. Kahlenberg, "The Future of Affirmative Action," New York, NY: The Century Foundation (2014), https://tcf.org/content/report/future-of-affirmative-action/.

74 Sean F. Reardon, Rachel Baker, Matt Kasman, Daniel Klasik, and Joseph B. Townsend, "Can Socioeconomic Status Substitute for Race in Affirmative Action College Admissions Policies? Evidence from a Simulation Model," Stanford: Center for Education Policy Analysis, 2017, https://eric.ed.gov/?id=ED580828.

75 Matthew M. Chingos, "Are Minority Students Harmed by Affirmative Action?" Washington: Brown Center on Education Policy at Brookings, 2013, https://www.brookings.edu/research/are-minority-students-harmed-byaffirmative-action/.

${ }^{76}$ William G. Bowen, Matthew M. Chingos, and Michael S. McPherson, Crossing the Finish Line: Completing College at America's Public Universities, Princeton University Press, 2009, https://press.princeton.edu/books/paperback/9780691149905/crossing-the-finish-line.
}

77 Mark C. Long, "Changes In the Returns to Education and College Quality," Economics of Education Review 29 , no. 3 (2010): 338-347, https://doi.org/10.1016/j.econedurev.2009.10.005.

78 Sean F. Reardon, Rachel Baker, Matt Kasman, Daniel Klasik, and Joseph B. Townsend, "Can Socioeconomic Status Substitute for Race in Affirmative Action College Admissions Policies? Evidence from a Simulation Model," Stanford: Center for Education Policy Analysis, 2017, https://eric.ed.gov/?id=ED580828. 


\section{Streamlining the College Application Process}

Low-income and racial and ethnic minority students often undermatch in the college admissions process, either not applying to-or not enrolling in - the most selective schools for which they are qualified. ${ }^{79}$ Research suggests that minimizing the barriers students face while applying can increase the number of applications low-income students submit. For example, one study found that a 13 percent decrease in application costs led students to submit one additional college application. ${ }^{80}$ Additionally, a project that distributed information about college applications and fee-waivers to high-achieving high school students observed a 19 percent increase in applications from students who recalled receiving an information packet. Of those students, the likelihood of enrolling in a school with which they "matched well" increased by 41 percent. ${ }^{81}$

Some states have also explored automatic admissions policies for in-state students at public colleges. In 2015, Idaho began automatically admitting its public high school seniors into all or a portion of its public colleges, depending on the student's GPA and SAT/ACT scores. ${ }^{82}$ The Texas Top Ten Percent Plan follows a similar but more restrictive logic, and the policy has resulted in more low-income students attending selective colleges. ${ }^{83}$ However, whereas the Texas plan only guarantees admission for a select group of students and still requires a more formal application process, the Idaho program gives all students an admission decision prior to submitting applications. The impacts of the Idaho plan are still being explored. However, universal automatic admissions appears to be a promising mechanism for removing a barrier that results in historically underserved students being overrepresented in limited-resource schools and instead gives talented students the opportunity to enroll at the most selective public colleges. ${ }^{84}$

Private organizations have also demonstrated that strategies to mitigate information barriers in the application and admissions processes can improve access to and success at well-resourced colleges and universities. The College Match Program, for instance, piloted an advising model to

\footnotetext{
79 "Increasing College Opportunity for Low-Income Students," The Executive Office of the President, 2014, https://obamawhitehouse.archives.gov/sites/default/files/docs/increasing college opportunity for lowincome students report.pdf.

80 Jonathan Smith, "The Effect of College Applications on Enrollment," The BE Journal of Economic Analysis \& Policy 14, no. 1 (2013): 151-188, https://doi.org/10.1515/bejeap-2013-0002.

${ }^{81}$ Caroline Hoxby and Sarah Turner, "Expanding College Opportunities for High-Achieving, Low Income Students," Stanford Institute for Economic Policy Research Discussion Paper 12 (2013), https://siepr.stanford.edu/research/publications/expanding-college-opportunities-high-achieving-low-income-students.

82 Josh Logue, "A New Statewide Initiative Automatically Admits Graduating Seniors to College in Idaho," Inside Higher Ed (November 30, 2015), https://www.insidehighered.com/news/2015/11/30/idaho-direct-enrollment-programautomatically-admits-high-school-seniors-public.

${ }^{83}$ Kalena E.Cortes and Jane Arnold Lincove, "Match or Mismatch? Automatic Admissions and College Preferences of Low-And High-Income Students," Educational Evaluation and Policy Analysis 41, no. 1 (2019): 98-123, https://doi.org/10.3102/0162373718813360.

84 Rick Seltzer, “A Wet Blanket on Idaho's Blanket Admissions," Inside Higher Ed (October 1, 2018), https://www.insidehighered.com/admissions/article/2018/10/01/panelists-highlight-drawbacks-idahos-much-praisedautomatic-admissions.
} 
encourage high-achieving students at low-income high schools to apply to more selective colleges. Researchers studying the project found that students are less likely to undermatch -in terms of college selectivity - when they learn about potential match schools, start the college planning process early, and receive guidance throughout the process. ${ }^{85}$ Another example is the Posse program, which conducts its own assessment of students who would typically undermatch to competitive schools-both public and private-in order to identify them to admissions officers. The program also uses a cohort model to support student retention, and college graduation rates among participating students are high. ${ }^{86}$ Both of these programs focus on the most selective institutions. However, they highlight approaches that can potentially scale to include a larger set of students and institutions.

Providing information about potential college matches serves as a key mechanism for reducing undermatch. Including a list of well-resourced institutions that correspond to a student's academic profile with the delivery of high school report cards may be one way of conveying this information. Another option is providing user-friendly websites that enable students to effectively find and compare institutions and the resources they have for students. The College Scorecard was one attempt at providing this information, offering an interactive tool to inform students of average costs, earnings, and completion rates. ${ }^{87}$ Alternatively, the Tennessee Promise scholarship includes required mentoring sessions to help students navigate the admissions process. This mentoring aspect provides an opportunity for elements of the College Match program to be scaled up.

State-administered college entrance exams may also provide opportunities to reduce information barriers. Although there is a broader move towards test-optional policies, roughly half of states currently require high school students to take the SAT or ACT as part of their graduation requirements. ${ }^{88}$ Low-income students and racial and ethnic minority students are less likely to take admissions exams which, in turn, may limit their postsecondary options. Moreover, colleges use lists of students who take these exams for outreach and recruiting purposes. So long as college entrance exams are part of the admissions process, states should expand opportunities and incentives for historically underserved students to participate.

States that provide widespread access to or require high school graduates to take the SAT/ACT may also consider requiring the Posse Program assessment, or something similar, in an attempt to triangulate potential match schools. With state mandates of testing for high school graduation, policymakers can implement outreach programs that use grades, SAT/ ACT scores, and the leadership assessment to provide institutional matches. Policymakers can view these

\footnotetext{
${ }^{85}$ D. Crystal Byndloss, Rebecca Coven, Yana Kusayeva, Christine Johnston, and Jay Sherwin, "In Search of a Match: A Guide for Helping Students Make Informed College Choices," New York, NY: MDRC, https://www.mdrc.org/sites/default/files/CollegeMatch 2015 UsersGuide\%202016Rev\%20Final.pdf.

${ }^{86}$ Posse Foundation, "Facts and Figures," https://www.possefoundation.org/posse-facts.

${ }^{87}$ U.S. Department of Education, "College Scorecard," https://collegescorecard.ed.gov/.

${ }^{88}$ Catherine Gewertz, "Which States Require Students to Take the SAT Or ACT," Education Week 36 (2017): 21, https://www.edweek.org/ew/section/multimedia/states-require-students-take-sat-or-act.html.
} 
independent organizations as labs that pilot innovative match programs, and then scale up the most successful interventions.

It is important to note that an emphasis on encouraging students to apply to and enroll in the most selective institutions is based on research showing us that these institutions are highly successful in graduating students. ${ }^{89}$ This success is, in part, due to the level of resources available at these institutions. However, the success of students who attend selective institutions is likely also related to entrenched notions of prestige and strong alumni networks. Even after controlling for college characteristics as well as students' academic performance and sociodemographic background, students who graduate from a highly selective college still earn more than graduates from less selective colleges. ${ }^{90}$ For this reason, increasing the resources available to less selective institutions is unlikely to eliminate inequities entirely, and undermatching is a legitimate concern. Nevertheless, closing the resource gap across institutions can still be an effective way to narrow disparities in outcomes, particularly given the extent of funding discrepancies between institutions. Below we discuss strategies for bolstering less-resourced institutions.

\section{Expanding Public Resources}

One way to improve access to well-resourced institutions is by expanding the supply of wellresourced institutions. In order to do this, policymakers must make a commitment to increase funding for a broad range of colleges and universities. The Great Recession in 2008 resulted in large cuts to state higher education spending, and as of 2018, only nine states are funding colleges at pre-recession levels. ${ }^{91}$ More concerning is that 11 states are funding colleges at lower levels than during the recession. ${ }^{92}$ The distribution of funds across institution types and sectors also creates large disparities in resources. For example, doctoral institutions-which servea much lower share of underrepresented groups in higher education ${ }^{93}$ _receive an average of \$8,200 per FTE in state appropriations. However, community colleges, bachelor's degree, and

\footnotetext{
89 Joel McFarland, Bill Hussar, Jijun Zhang, Xiaolei Wang, Ke Wang, Sarah Hein, Melissa Diliberti, Emily Forrest Cataldi, Farrah Bullock Mann, Amy Barmer, "The Condition of Education," Washington: National Center for Education Statistics (2019), https://nces.ed.gov/pubsearch/pubsinfo.asp?pubid=2019144.

90 Witteveen, Dirk, and Paul Attewell. "The earnings payoff from attending a selective college." Social Science Research 66 (2017), https://www-sciencedirectcom.ezproxy.cul.columbia.edu/science/article/pii/S0049089X16301430?via\%3Dihub.

91 Sophia Laderman, Dustin Weeden, and Andrew Carlson, "2018 State Higher Education Finance," Boulder, State Higher Education Executive Officers Association (2019), https://sheeomain.wpengine.com/wpcontent/uploads/2019/04/SHEEO SHEF FY18 Report.pdf.

92 Ibid.

93 The Woodrow Wilson National Fellowship Foundation, "Diversity \& The Ph.D.: A Review of Efforts to Broaden Race \& Ethnicity in U.S. Doctoral Education," Princeton: WWNFF (2005), https://files.eric.ed.gov/fulltext/ED536864.pdf.
} 
master's degree institutions all receive less than \$5,500 per FTE in appropriations. ${ }^{94}$ Although the cost of providing an education may vary across institutions, inequitable funding levels perpetuate inequities in access to educational resources and opportunities.

Given the current public health crisis, state postsecondary budgets are likely to contract. With a weakened economy and reduced state revenues, higher education systems are preparing for funding cuts similar to those during the Great Recession. However, the loss of auxiliary revenues and potential near-term enrollment declines is likely to make the financial impact of COVID-19 on colleges significantly worse than 2008. In states where public higher education funding still has not recovered from the last recession, new cuts may put incredible financial strains on institutions. Increased higher education spending is unlikely if the economy contracts, but policymakers should consider how funding cuts are distributed across institutions. While not an ideal mechanism for addressing inequity, cutting funding in a way that minimizes disparities across institutions and student groups is one way to reduce inequities in resources.

Community colleges must be included in states' strategies to address institutional resource disparities and expand access to well-resourced colleges. Two-year colleges serve the highest share of students from underrepresented racial groups, ${ }^{95}$ and the majority of low-income students are enrolled at two-year colleges. ${ }^{96}$ However, community colleges receive one-third the amount that public flagship institutions receive and roughly one eighth the amount that private, high-endowment institutions receive in public appropriations and tax subsidies per FTE student. ${ }^{97}$ The disproportionate share of low-income and racial and ethnic minority students in two-year colleges, combined with the relative lack of investment in these colleges, exacerbates spending disparities across student groups. In 40 states, public higher education institutions spend fewer dollars on Black students than their white peers. ${ }^{98}$ In turn, these funding disparities have serious implications for inequities in student outcomes. Nationally, fewer than 40 percent of students who begin their postsecondary career at a public two-year college complete a degree within six years, and only 27.5 percent of Black students do. ${ }^{99}$

\footnotetext{
94 The Institute for College Access \& Success, "Dire Disparities: Patterns of Racially Inequitable Funding and Student Success in Public Postsecondary Education," Oakland: TICAS (2019), https://ticas.org/wpcontent/uploads/2019/09/dire-disparities.pdf.

95 Joelle Fredman, "Report: Community Colleges Need More Support to Graduate Underrepresented Students," 2019, https://www.nasfaa.org/newsitem/19306/Report Community Colleges Need More_Support to Graduate Underrepresented Students.

96 Joselynn H. Fountain, "The Postsecondary Undergraduate Population: Student Income and Demographics, U.S. Library of Congress, Congressional Research Service, R45686 (2019), https://fas.org/sgp/crs/misc/R45686.pdf.

${ }_{97}$ Jorge Klor de Alva and Mark Schneider, "Rich Schools, Poor Students: Tapping Large University Endowments to Improve Student Outcomes," San Francisco: Nexus Research and Policy Center (2015), http://nexusresearch.org/wpcontent/uploads/2015/06/Rich Schools Poor Students.pdf.

98 Elizabeth Davidson Pisacreta, Daniel Rossman, and James Dean Ward, "Race and Higher Education: Disparities in Opportunities," Ithaka $S+R$, (forthcoming).

${ }^{99}$ Doug Shapiro, Afet Dundar, Faye Huie, Phoebe K. Wakhungu, Ayesha Bhimdiwala, Sean E. Wilson, "Completing College: A National View of Student Completion Rates - Fall 2012 Cohort (Signature Report No. 16)," Herndon:
} 
In addition to adequately funding community colleges, state policy can directly support postsecondary opportunities for racial and ethnic minority students by increasing financial support to historically Black colleges and universities (HBCUs) and minority serving institutions (MSIs). A recent study examined the resources available to HBCUs and found that both public and private HBCUs spend less, receive fewer donations, and have smaller endowments (in per FTE values) than their predominantly white counterparts. HBCU students also tend to have fewer financial resources and, as a result, borrow more and at higher rates. ${ }^{100}$ Despite these disparities, however, students who attend HBCUs tend to have better outcomes-including graduation rates - than similar students at other institutions. ${ }^{101}$

State funding decisions directly impact the resources available to HBCUs and MSIs. For example, after states implement performance-based funding (PBF) policies, the average MSI receives a decreasing share of state appropriations when compared to predominantly-white institutions. ${ }^{102}$ Moreover, MSIs in PBF states receive fewer dollars than MSIs in non-PBF states. ${ }^{103}$ Well-resourced MSIs would be in a better position to compete with selective public institutions in terms of both educational quality and financial aid for top students. Additional funding for MSIs can help increase the number of well-resourced institutions available to students and, specifically, increase the number of seats available to racial and ethnic minority students.

Recent research also suggests that increasing racial and ethnic minority enrollment in public higher education is linked with a steady divestment from state governments. ${ }^{104}$ These troubling funding trends stand to exacerbate inequity in postsecondary opportunities and access to wellresourced colleges. A commitment to funding a range of institutions sufficiently to create a parity in resources would be an important step towards improving access to well-resourced institutions for historically underserved students.

National Student Clearinghouse Research Center (2018), https://nscresearchcenter.org/wpcontent/uploads/SignatureReport16.pdf.

100 Katherine M. Saunders, Krystal L. Willams, Cheryl L. Smith, "Fewer Resources, More Debt: Loan Debt Burdens Students at Historically Black Colleges and Universities," Washington: Frederick D. Patterson Research Institute, UNCF (accessed July 2020), https://eric.ed.gov/?id=ED573646.

101 David. A. Tandberg, "Response to Senators Doug Jones, Elizabeth Warren, Kamala Harris, and Catherine Cortez Masto's Student Borrow of Color Solicitation Letter," State Higher Education Executive Officers Association (2019), https://sheeoorg.wpengine.com/wp-content/uploads/2019/03/Tandberg Response to Senators 2-15-19 0.pdf.

102 Nicholas Hillman and Daniel Corral, "The Equity Implications of Paying for Performance in Higher Education," American Behavioral Scientist 61, no. 14 (2017): 1757-1772, https://doi.org/10.1177\%2F0002764217744834.

103 Ibid.

104 Barrett J. Taylor, Brendan Cantwell, Kimberly Watts, and Olivia Wood, "Partisanship, White Racial Resentment, and State Support for Higher Education," The Journal of Higher Education, (2020), DOI: $10.1080 / 00221546.2019 .1706016$. 


\section{Increasing Affordability}

The price of college puts a postsecondary education out of reach for many. Low-income students, in particular, may struggle to afford the full cost of attendance, which includes books, fees, and housing. Well-resourced colleges not only receive more state funding but also typically have higher levels of tuition revenue. That is, these institutions have more resources in part because they charge more. The inability of low-income students to afford high tuition prices inherently limits their access to this set of well-resourced colleges. While state financial aid programs help offset these costs, the majority of families with college students still spend more than 20 percent of their annual income on higher education tuition and fees after grants are distributed. ${ }^{105}$ Additionally, nearly one third of students who apply for and are eligible for state financial aid do not receive any as a result of insufficient funds. ${ }^{106}$ Increasing public support to offset tuition costs may help improve access for historically underserved students. Additionally, strategies to simplify and streamline the FAFSA process will also be important to improve FAFSA completion and ensure that more students are aware of and can access all federal aid for which they are eligible.

In efforts to improve affordability at well-resourced institutions, policymakers should consider the special circumstances of undocumented students. Of the roughly 65,000 undocumented students who graduate from U.S. high schools each year, only five to ten percent of them enroll in college. 107 Oftentimes, affordability of higher education is the primary obstacle for undocumented students, especially because they do not have access to federal student aid, and many states do not allow undocumented students to qualify for in-state tuition. ${ }^{108}$ Research has shown that offering in-state tuition increases the likelihood that undocumented students will be able to pay for college. ${ }^{109}$ Several studies have also concluded that adopting policies that aid undocumented students can positively impact immigrant students' aspirations of pursuing postsecondary education. ${ }^{110}$ Noncitizen Hispanic students in states with an in-state tuition policy for undocumented students were 1.5 times more likely to enroll in college than similar

\footnotetext{
105 Sara Goldrick-Rab, "Paying the Price: College Costs, Financial Aid, and the Betrayal of the American Dream." University of Chicago Press, 2016.

106 Meredith Kolodner, "Eligible for Financial Aid, Nearly a Million Students Never Get It," New York: The Hechinger Report (2018), https://hechingerreport.org/eligible-for-financial-aid-almost-one-third-of-students-never-get-it/.

107 BestColleges, "College Guide for Undocumented Students," Houston: BestColleges (accessed October 2019), https://www.bestcolleges.com/resources/undocumented-students-guide.

108 University of the People, "States that Offer In-State Tuition to Undocumented Students," University of the People (accessed October 2019), https://www.uopeople.edu/blog/us-states-that-offer-in-state-tuition-rates-toundocumented-students-and-what-to-do-if-your-state-isnt-one-of-them/.
}

${ }^{109}$ Amy Nunez and Gretchen Holthaus, "In-State Tuition for Undocumented Students: A Policy Analysis," Journal of the Student Personnel Association at Indiana University (2017): 47-63, https://scholarworks.iu.edu/journals/index.php/jiuspa/article/view/23697. 110 Ibid. 
students residing in states without such a policy. ${ }^{111}$ Furthermore, in-state tuition policies are estimated to lead to an eight percentage point decrease in the proportion of Mexican foreignborn noncitizens that drop out of high school. ${ }^{112}$

Federal law has complicated state policy on the issue of college affordability for undocumented students. Without a federal mandate, individual states determine if undocumented students should receive in-state tuition, their financial aid eligibility, and their ability to enroll in college at all. ${ }^{113}$ Twenty states currently have policies allowing undocumented students to pay in-state tuition, although three states only extend this benefit to noncitizens enrolled in DACA. ${ }^{114}$ California, Minnesota, New Mexico, Oregon, Texas, and Washington currently have policies that help undocumented students access financial aid. ${ }^{115}$ On the other hand, as of 2017, five states have prohibited in-state tuition rates for undocumented students, and two others have completely banned undocumented students from enrolling at any public institution. ${ }^{116}$ Research shows that undocumented students actually bring additional revenue to their schools and provide economic benefits to the state and community. ${ }^{117}$ Policies pertaining to noncitizens are one avenue for states to improve access to well-resourced institutions.

States must make targeted efforts toward lowering the affordability hurdle for low-income students. However, policies supporting college affordability should also take into account other aspects of a student's identity (e.g., undocumented status) in order to effectively address their specific barriers. By making well-resourced institutions more affordable, states can not only improve postsecondary access and outcomes, but are also likely to see outsized economic returns in the form of reduced public welfare expenditures and increased tax revenue.

\footnotetext{
111 Stella M. Flores, "State Dream Acts: The Effect of In-State Resident Tuition Policies and Undocumented Hispanic Students," The Review of Higher Education 33, no. 2 (2010): 239-283, https://doi.org/10.1353/rhe.0.0134.

112 Stephanie Potochnick, "How States Can Reduce the Dropout Rate for Undocumented Immigrant Youth: The Effects of In-State Resident Tuition Policies," Social Science Research 45 (2014): 18-32, https://doi.org/10.1016/j.ssresearch.2013.12.009.

113 Alene Russell, "State Policies Regarding Undocumented College Students: A Narrative of Unresolved Issues, Ongoing Debate and Missed Opportunities," American Association of State Colleges and Universities (2011), https://www.aascu.org/uploadedFiles/AASCU/Content/Root/PolicyAndAdvocacy/PolicyPublications/PM Undocument edStudents-March2011.pdf.

${ }^{114}$ Amy Nunez and Gretchen Holthaus, "In-State Tuition for Undocumented Students: A Policy Analysis," Journal of the Student Personnel Association at Indiana University (2017): 47-63, https://scholarworks.iu.edu/journals/index.php/jiuspa/article/view/23697.

115 Ibid.

116 Ibid.

117 Ibid; Patricia A. Pérez, "College Choice Process of Hispanic Undocumented Students: Implications for Recruitment and Retention," Journal of College Admissions, Winter (2010): 21-25, https://files.eric.ed.gov/fulltext/EJ874055.pdf
} 


\section{Increasing Oversight}

States play an important role in the oversight of colleges and universities. As part of the regulatory triad, states must authorize colleges to operate within their jurisdictions. ${ }^{118}$ States also manage consumer protections for students who may have been defrauded by institutions. Through these two regulatory avenues, state leaders can improve access to well-resourced institutions.

Well-resourced colleges have the benefit of spending more on students, and it is this spending that is associated with improved student outcomes. One way that state regulatory policy can influence the resources being spent on students is by mandating a minimum spending threshold. Such a threshold may prevent institutions from redirecting revenue toward inflated administrative salaries or, in the case of for-profit institutions, toward profits for owners and shareholders. Setting minimum spending levels can also help close the spending gap across institutions, and in turn, narrow disparities in outcomes.

State leaders should also consider their role in protecting students from exploitative colleges. Research suggests that states with strong regulatory environments have higher college completion rates and lower student loan default rates. ${ }^{119}$ Regulatory action against bad actors can be an indirect way to improve access to well-resourced institutions by eliminating exploitative colleges from the market, and it can put legal pressure on institutions to improve how they serve their students. In these ways, regulatory policy can reduce gaps in student outcomes by helping to raise the floor in terms of college quality.

Regulatory policy can help improve the overall quality of postsecondary options across both the nonprofit and for-profit sectors. However, significant regulatory attention has been paid to forprofit institutions in particular given their students, on average, have poorer outcomes than students at nonprofit institutions. For-profits also enroll disproportionate shares of historically underserved students. By regulating this sector more stringently and reducing predatory behavior, students will be less likely to fall prey to exploitative colleges and have a higher likelihood of attending a well-resourced institution.

\section{Conclusion and Remaining Questions}

Access to well-resourced institutions is associated with increased educational attainment and better long-term life outcomes. However, this access is largely stratified along socioeconomic, racial, and ethnic lines. Addressing inequitable access to a high-quality postsecondary education is both a moral and economic imperative for states. This inequity perpetuates social and economic inequalities. It also represents a missed opportunity for states in terms of returns on their investments into education and their citizens. A highly educated workforce is less likely to

\footnotetext{
118 Robert Kelchen, Higher Education Accountability, JHU Press, 2018, https://jhupbooks.press.jhu.edu/title/highereducation-accountability.

119 James Dean Ward, "Regulating for Equity? Estimating the Effects of State Regulation of For-Profit Colleges," Presented at the Annual Meeting of the American Education Research Association (2019).
} 
use social services and welfare assistance and more likely to boost tax revenue. In order for states to meet attainment goals and maintain a skilled labor force, closing equity gaps is of paramount importance.

In this policy brief, we discuss a range of ways to improve access to well-resourced institutions. We suggest states take a multi-pronged approach to addressing this issue. Increasing and equalizing funding across campuses, providing more direct routes to college through affirmative action policies and a streamlined admissions process, lowering financial burdens to hightuition/ high-resource institutions, and maintaining educational quality through strong oversight are all important ways states can reduce inequities in access to high-quality postsecondary opportunities. Through this broad set of levers, state leaders can simultaneously increase the supply of well-resourced institutions and decrease barriers to these institutions for historically underserved students. Both strategies will serve to reduce inequities and have positive social and economic impacts on states.

While this brief summarizes the potential benefits of a range of policies, it also points to important questions that still need to be answered. The following questions can guide future research to provide deeper insight into how state policy can increase access to well-resourced colleges:

- What level of resources is necessary to adequately serve students?

- Research shows that performance-based funding and state politics play an important role in the distribution of funding and access to resources for historically underserved students. What other state policies may have unintended consequences on access for these students?

- What are the effects of more streamlined admissions processes, such as the Idaho direct admissions program?

- How can information and mentoring programs be scaled up to improve access?

- How does information about institutional resources impact students' enrollment decisions? 